\title{
Synthesis of Arts in Soviet Architecture: stages of development, main directions, causes of their occurrence
}

\author{
Liudmyla Bachynska \\ Kyiv National University of Construction and Architecture \\ Povitroflotsky avenue 31, Kyiv, Ukraine, 03037 \\ ludmila bachina@ukr.net, orcid.org/0000-0002-6942-5627 \\ Received on 02.12.2019, accepted after revision on 02.09.2019 \\ https://doi.org/10.32347/tit2021.42.0102
}

\begin{abstract}
The history of the Soviet Union, its socio-economic, socio-political and socio-cultural life is unique in comparison with other countries. The USSR was created on the model of social development, expressed by European and Russian Utopian socialists and was grounded in the classics of Marxism-Leninism. So, the system of government, economic conditions and cultural activities of a society built on the hegemony of the proletariat was a long-running social experiment that conditioned the life of the Soviet people and influenced other countries as well.

The experiment of a country with total state property envisaged that the party leadership assumed responsibility for defining all spheres of political life - both internal and interstate relations - and inevitably formed unified programs of cultural activity and social development, managed them, and financed and tightly controlled their implementation. The Soviet people, the so-called "working masses", were forced to live and act under uniform rules. Depending on the planning of the political, economic and social life of the party leadership throughout the existence of the USSR, the country went through several stages, which differed in the directions of forming an architectural and urban planning environment that had to meet the tasks of state and ideological character. Familiarizing yourself with this unique experience and finding the reasons for its formation is important for understanding the trends of social development in the twentieth century.
\end{abstract}

Keywords: Soviet Union, Ukraine, sociocultural activities, influence of political and economic conditions, architecture and urban planning.

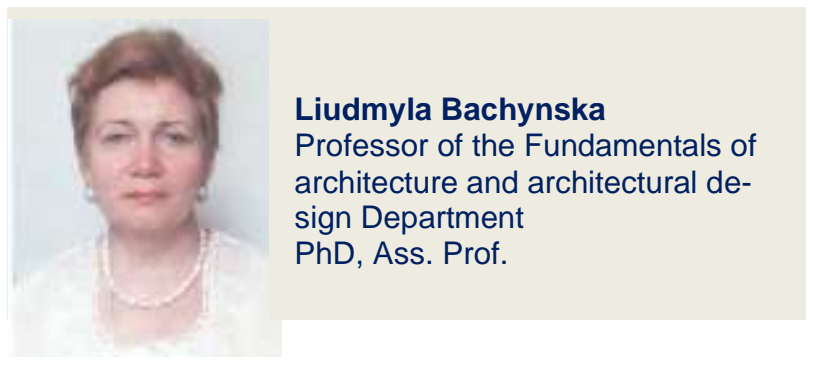

\section{THE INTRODUCTION}

It is known that for a complete idea of the depth and essence of the impact of cultural heritage on social development, it is necessary to study the historical heritage, analyze its value for the present, look for reasons for its formation in the past. Due to the length of time consideration, you can see a complete picture of cultural dynamics and forecast it for the future.

During the existence of our country in the USSR, together with it, Ukraine has undergone joint processes of economic development and state formation. It is important to study the parallels of the socio-historical and cultural development of the country in order to find the identity of architectural and cultural development and to justify the causes of Ukrainian identity when they exist, as well as to find out the ways of using the synthesis of arts in Ukrainian architectural and construction practice, which has always contributed to enhancing the desired effects in formation of architectural and urban planning environment. 


\section{THE PURPOSE OF THE RESEARCH}

So, the object of this study is the synthesis of arts in the architecture of Soviet Ukraine. The subject is the role and directions of the use of art synthesis in the architecture of Soviet Ukraine. The purpose of scientific research is to identify the causes of the use of art synthesis in different historical periods of political and economic development of Ukraine and to establish their role and main directions.

THE METHODS OF THE RESEARCH

Research methodology - the causation between the political and economic situation, foreign and domestic policy directions and socio-cultural activities; comparative analysis of the consequences of the formation of architectural heritage using the synthesis of arts at different stages of socio-historical development of our country in the Soviet era.

\section{THE RESULTS AND DISCUSSION}

The connection between the periods of historical, political and economic development of the country and socio-cultural activity of the population on the example of developing the principles of creating an architectural and urban planning environment has been proved in many author's publications [1 - 4] and many others. They identify the main phases of political and economic development of our country during its existence in the USSR, which are caused by foreign and domestic political activity - these are: the first after 1917 - the stage of search for directions of optimization in the system of government and management, which was distinguished by diversity proposals, even going back for a while to the old forms of the capitalist economy (the so-called NEP) - 1920s - 1932; the stage of establishing a totalitarian system of government headed by a leader and with total state property, characterized by the construction of socialism (the so-called «Stalinist» period) - 1937 - 1953 and the stage of a collegial system of government based on a one-party system headed by the SecretaryGeneral. At that time, in 1955 - 1985, attention was paid to social programs and the direction of building further economic development communism - was being worked out.

Each of these stages of socio-political and economic development was preceded by transitional stages, which were characterized by the search for new directions, understanding of certain state-social needs, the gradual transition to changes in management systems and corresponding changes in the directions of formation of architectural and urban planning environment. All of them that are listed the three main and three transitional stages have shown signs of centralization of the management system in the orientation of planning, financing, implementation of the system of control over the implementation of the planned programs and the system of responsibility and punishment for failure to meet the scheduled time and amount of tasks.

The state-party government, which took responsibility for resolving all economic issues, disseminated the principles of social ideologization, which was reflected in various areas of cultural activity, including the means of creating an architectural and urban planning environment.

The latter became the most prominent object of propaganda of state ideology, which not only was formed on the basis of stateideological programs, but also forced the population to constantly be surrounded by symbols of totalitarianism.

So, let's consider the main directions of formation of architectural and urban planning environment, corresponding to the three stages of political and economic development of the USSR and Ukraine that was in it. The first stage of the search for directions of political and economic development was characterized by a variety of proposals of representatives of different architectural schools, in each of which experts tried to prove the priority of their direction among others in order to determine the correspondence to the Sovietsocialist goal. These were representatives of the old classical school; of eclecticism, which prevailed in the pre-October times and, following the tradition of «architecture of choice» by A. Ikonnikov's definition [5], provided an opportunity to freely interpret the artistic and 
aesthetic image of an architectural structure by architectural means; efforts were made to create a purely Ukrainian school on a national basis, which caused the greatest concern on the part of the authorities. M.S. Ilchenko notes: "In the 1920s, the avant-garde trend in Soviet architecture was a colorful mosaic consisting of many currents, groups and schools that professed different artistic principles and set different creative tasks. Many of these groups lacked a solid theoretical platform or clear setup and were therefore forced to navigate between more influential currents, periodically joining one or the other community of architects» [6]. Among them, the direction of architectural formation generated by the Russian Revolution had a special status, it was too straightforward to reflect the symbolic and ideological content of a new type of state. This is constructivism, which by its industrial forms, transferred to the social environment, was doomed to embed in the public opinion the idea of a new socio-political system resulting from the victory of workers and peasants. That is why the process of intensifying the design and construction of various clubs and palaces as centers of cultural and mass work (the palaces of communism, Soviets, labor, workers, railways, arts, pioneers, etc.) [7] has unfolded, which did not stop in the following periods.

Analyzing the experience of constructivism in the construction of buildings, we can conclude that the architectural form in this direction of styling was chosen as a solid monumental image of the undeniable victory of workers during the Soviet times (see Fig. 1, $a$, $b, c)$. As history of architecture proves, monumentality does not need decorativeity, it should impress with its laconic large-scale forms. So, constructivism was not characterized by the use of small-sized decorative parts. Rather, the decorative shape was determined by horizontal lines, which were supposed to reflect the idea of the dynamics of social life (Fig. 1, d) and complex combinations of geometrically simple volumes (Fig. 1,e). The symbolic content of the architecture of constructivism over time began to manifest itself in the formation of buildings that resembled technical achievements or symbolized signs of statehood of a new type. This was especially characteristic of the Russian Federation (there is a construction in the form of a plane, an opera house in Rostov-on-Don - in the form of a tractor, and an opera house in Arkhangelsk in the form of a huge grandstand, Fig. 1, $h$, same, factory-kitchen in Samara displays the sickle and hammer). What we define as a synthesis of the arts in architecture can be determined in relation to the direction that is viewed as the Soviet-ideological symbolism of a large-scale architectural form. In Ukraine, the manifestations of symbolism in the form of a building were much more modest (for example, the facade of the Railway Culture Palace in Kharkov has a surface like an accordion; in Fig. $1, f, g$, the notorious building of Ukrainian writers destroyed by Soviet power in Kharkiv under the name «Word» has the form of the letter $« \mathrm{C} »$.

The second stage of the formation of Soviet architecture, which coincides with the time of a new period of economic and political development, is the stage of embodiment of pseudoclassicism in the architectural and urban environment, and after the Second World War, for the well-known reasons, due to the so-called «victory over fascism», pseudo-empire that was based on the prototype of the eclecticism of the Russian Empire (see Fig. 2, $a, b, d$ ).

The transition from horizontal division of the facade in constructivism to the vertical one, characteristic of the newly chosen direction in architecture, took place against the backdrop of fierce criticism of the authors of architectural works by representatives of the party elite. It was about a «boxed» monotonous architecture, about the desire to show the «mechanization» of the public space, about the discrepancy between the theme of technization in architecture to the living human being [6 - 8]. Yes, Russian researcher Selivanova O.N. writes that the avant-garde (constructivism) in this new context was viewed twice in retrospect, because it denied the notion of physicality in general, and in addition, the new era judged it by its own standards presenting constructivist buildings as ill, defective ordismembered dead bodies [8]. She, 


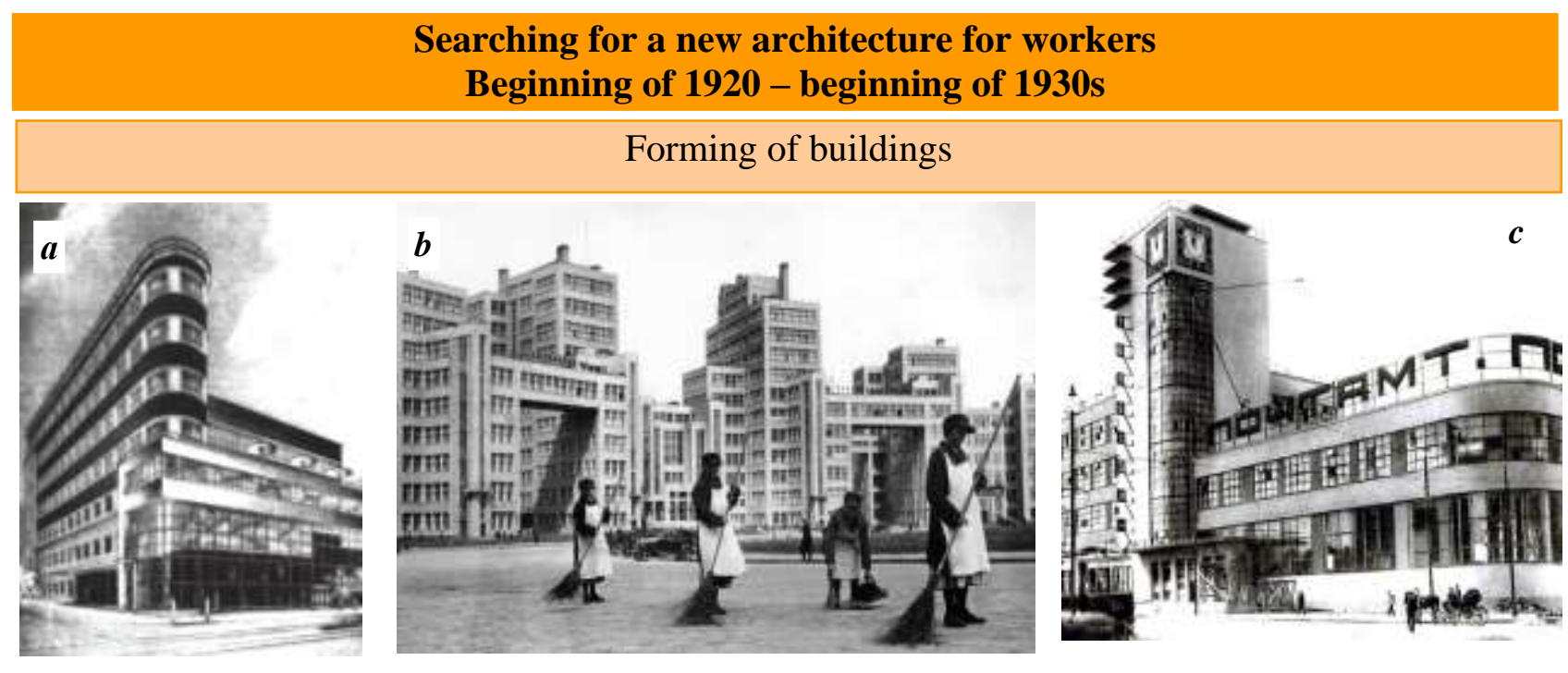

Decorative form and its elements
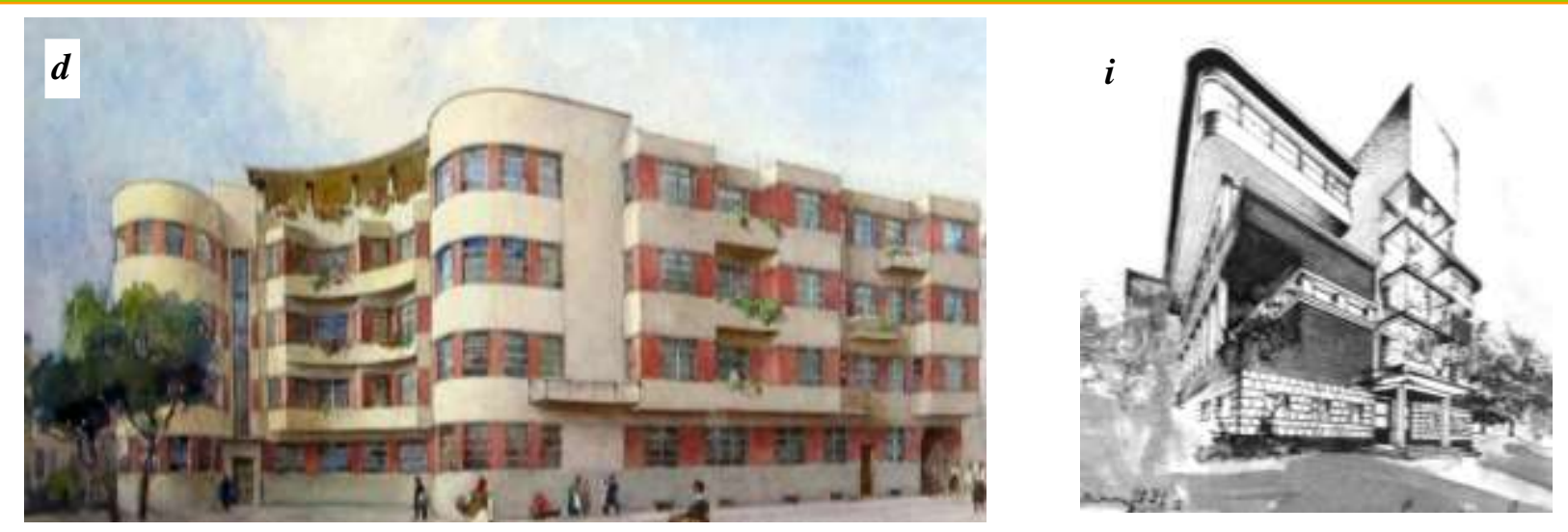

Form symbolism as content
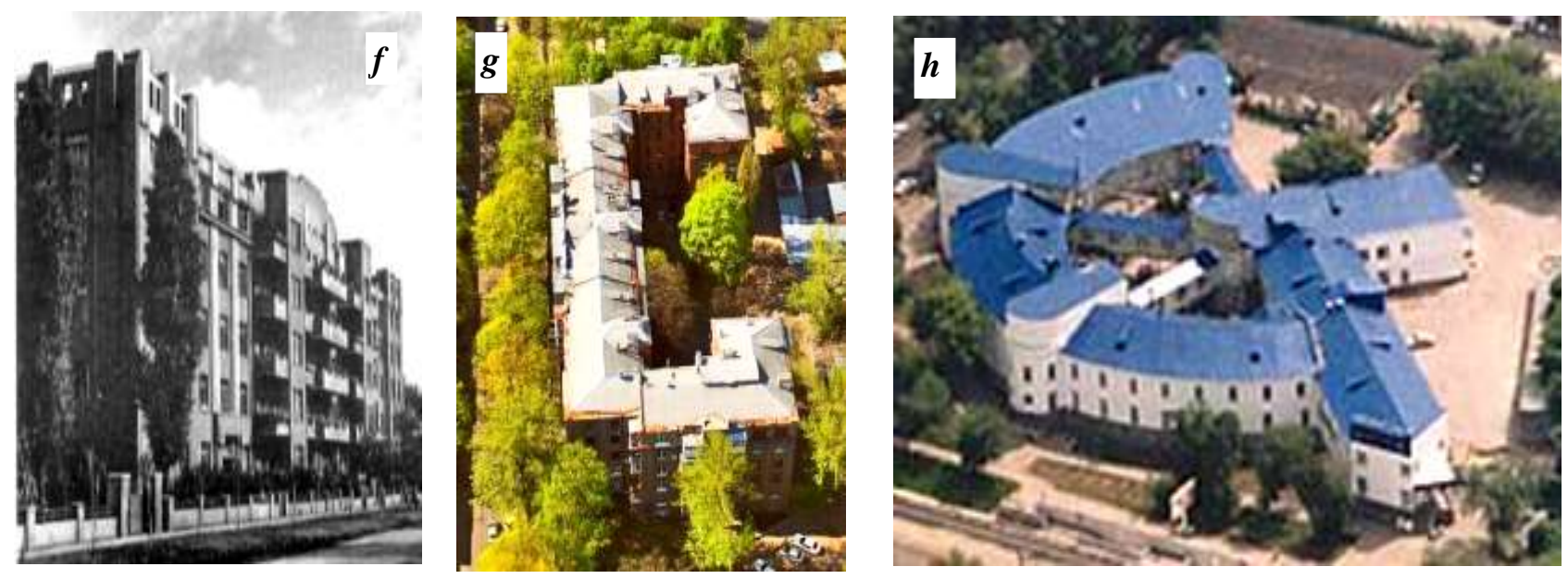

Fig.1. Examples of new building architecture for workers in the style of constructivism: $a$ - project of the House of Books erected on the site of the Central Department Store, str. Khreshchatyk, 44, Kyiv, Holovproject, 1930s; $b$ - Derzhprom, Sq. Svoboda, Kharkiv, arch. S.S. Serafimov, S.M. Kravets, M.D. Felger, 1925 - 1928; c - Main Post Office, Sq. Pryvokzal'na, 2, Kharkiv, arch. A. Mordvinov, 1927 - 1929; $d-1$ st doctor's house, str. V. Zhytomyrska, 17, Kyiv, arch. P. Alyoshin, $1928-1930 ; e$ - project of Dynamo restaurant, Petrovska alley, 3, Kyiv, arch. J. Karakis, P. Savich, 1932; $f-g-$ apartment building of the writers «Word», str. Kultura, 9, Kharkiv, arch. M. Dashkevich, $1926-$ 1930: house facade and aerial view; $h$ - factory kitchen of plant named after Maslennikov, Samara, Russia, arch. K. Maximova, 1932. 


\section{The period of Soviet historicism \\ $1954-1985$}
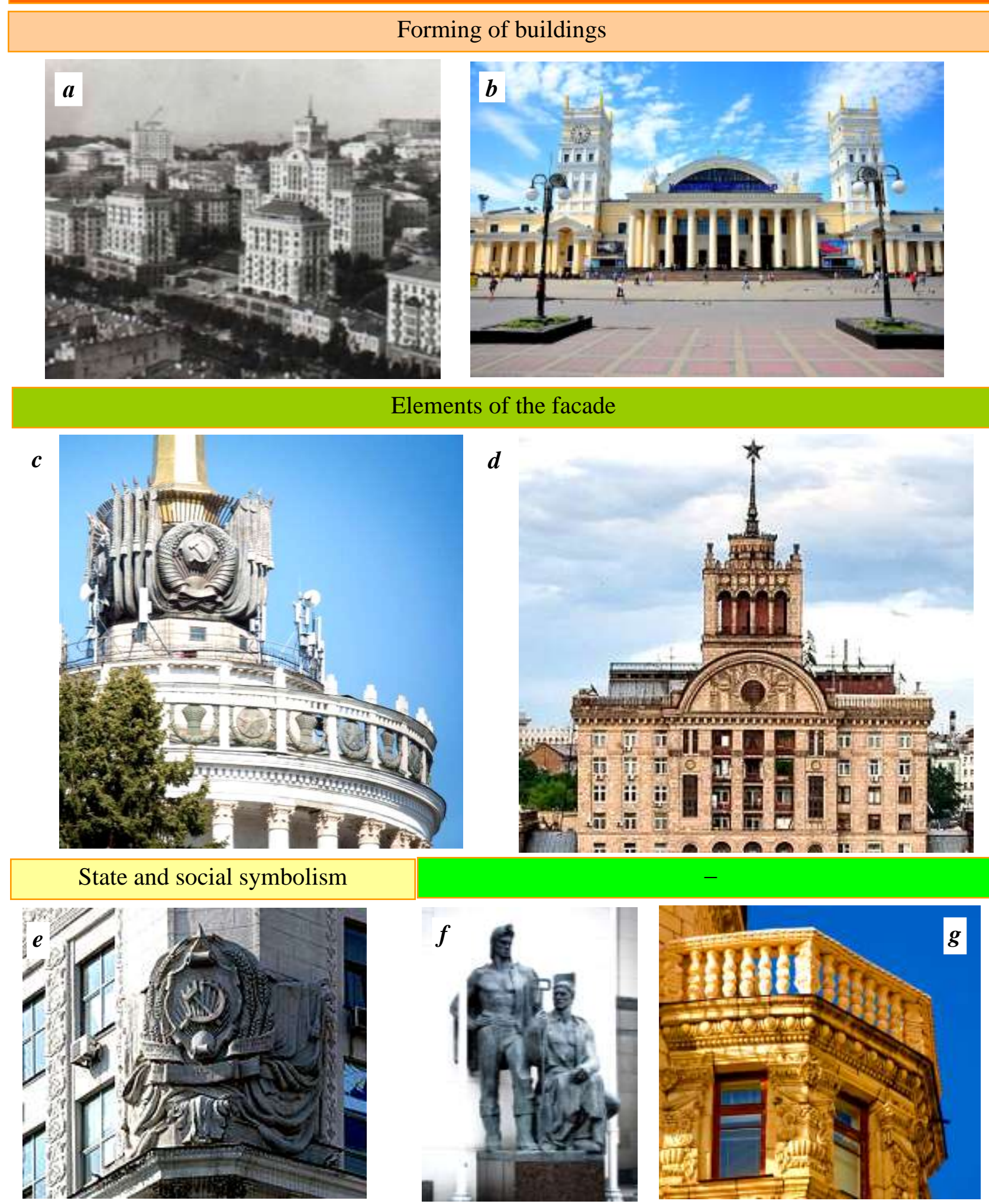

Fig.2. Examples of the shaping of buildings and the synthesis of the arts as a means of state and social symbolism in the period of historicism: $a$ - panorama of buildings on the str. Khreschatyk, Kyiv; $b-$ Railway station, Kharkiv, arch. G Voloshin et al., 1952; $c$ - VDNH, main pavilion, Kiev, arch. B. Gégerine, 1949; $d$-building on the str. Khreshchatyk, No. 25, Kyiv; $e$-building on Sq. Of the Constitution, Kharkiv, arch. V. Petit, Y. Chebotaryova, V. Kostenko, $1947-1950 ; f$-sculptures at the entrance to the Verkhovna Rada, Kiev, arch. V. Zabolotny; $g$ - bay window of house № 23, str. Khreschatyk, Kyiv. 
quotes the famous Soviet urban planner M. Milyutin: "If the creation of new forms of human beings depended on constructivists, they would have exposed all his skeleton, tendons, nervous system, and intestines. What is the job of such an architect to create artistic images?» Thus, the eclecticism of architecture was in keeping with the contemporary needs of the Soviet state at the time - to create an ideologically designed environment through various means. When working on the compositional fantasies of the Palace of Communism, Ya. Chernikhov wrote: «Architecture, as the art of spatial forms, as an image constantly visible and tangible, is one of the powerful factors for convincing propaganda of the great ideas of communism. Undoubtedly, the heroics of the Stalin era will find in architectural structures that expressive and laconic image that puts forward a special category of compositional interpretations of spatial forms. Magnificence and pomp, rise and triumph, joy and happiness, power and strength...» [7]. The «heroics of the Stalin era» coincided with the deification of the leader, at least the main professional editions of architecture in every way emphasized this, reflecting on the great inspirer of Soviet architecture, who "created the doctrine of socialist realism - the principle and creative method of the Soviet art, about a galaxy of architects, who «guided by ideas - ideas of Marxism-Leninism... They are the creators of the best examples of Soviet architecture, characterized by high ideology and partisanship, ... full conformity of ideological content and artistic form, critical development of the classical heritage of the past, the most progressive national traditions of their people» [9]. The Bulletin of the Academy of Architecture of the USSR for the 1950s prints the editorial article «Under the glorious banner of Soviet democracy», the content of which resembles an essay on the personality of the Generalissimos: «Stalin! - It is the most expensive and most native name for all the Soviet people and the workers of the whole world, which is spoken with love and pride in all corners of our vast homeland... For us, Soviet people, there is no the most dear and most native person than our leader and teacher Joseph Stalin» [10].
In order to justify the applied architectural forms and details borrowed from the historical heritage of the Russian Empire (which were not even hidden, and in print publications it was possible to meet praiseworthy reviews on works of artists of classical architecture [9]), in the architecture of buildings began to spread symbolic signs of the new power and its economic and political system. That is, the mass use of state and social symbols (state in the form of attributes of power - state and republican coats of arms - Fig. 2. c, $e-$ stars, flags, sickle and hammer as signs of the workingpeasant power; social - the tools of labor, the sun with rays, ribbons, flowers that symbolized the happy life of the people in the Soviet socialist state). In the pre-war period of «Stalinism» in architecture, one can find the use of the theme of happy life of workers, which was decorated with reliefs depicting people in the process of work and rest. Over time, this tendency in some examples began to turn into significant in size and complex in number of used decorative elements of the composition, which contained vases, balusters (Fig. 2, g), capitals of pilasters and more.

After World War II, sculptures of a large size of an individual appear in work or sportswear with certain tools in their hands, which adorned the facades of buildings and personified the Soviet people. In Kyiv, such examples of sculpture use are: the building of the Verkhovna Rada of Ukraine, separate dwellings of the so-called «Stalin» time, and the central street of Kyiv - Khreschatyk - according to the reconstruction project it was to be transformed into a museum of cement figures, according to O. Mokrousova [11]). The sculptures were used not only in the decoration of the facades of buildings - in their completion as the most significant place, at the base near the entrance - closer to the conditions of perception (Fig. 2,f), but also as dominant elements in symmetrically constructed large-scale compositions of architectural and spatial organization of urban centers and town-planning ensembles. Here, the sculpture was already detached from a separate building, spatially was reinforcing the emphasis in the structureof the town-planning ensemble, becoming the 
main landmark in creating a single composition, which revealed the main content that glorified power, the state, the conditions of Soviet life (see materials of competitive projects after the Second World War [12]).

Thus, the Stalinist state system actively used the synthesis of arts in the form of plastic arts to enhance the effect of decoration of architecture, focused on a clearly defined ideological direction, from their decorative qualities and ending with large compositions of several figures or too large in size of a single figure. On the one hand, there was the simplicity of the structure of the spatial organization on the basis of axial symmetry, on the other, the complexity of constructing the most architectural form with variations in accordance with the chosen theme of classical architecture and the imaginative conditions of perception of the sculptural composition, which was arranged and allowed it to be viewed from different points of space, in the light and shade that changed position during the day mode. This was increasing the overall impression and met the conditions of formation on the basis of increased decorative at the time.

In parallel with the implementation of a course designed by the party to «creatively rethink classical heritage» in Soviet architecture, which was adopted at the First Congresses of Architects of the Soviet Union and Ukraine in 1937 [13, p. 9], according to which specialists and scientists of the Academies of Architecture of the USSR and Ukraine continued to work hard, Ukrainian architects were looking for ways to improve construction in the direction of economic housing structure, development of typical industrial products and new construction materials. This was also determined by the tasks of the party leadership. These very first works on the industrialization of construction constituted the experience which in the following helped to define a new course in construction, proclaimed by the Resolution of the Central Committee of the CPSU and the Council of Ministers of the USSR «On Combating Surpluses in Architecture» [14], and in full to create a base, on which began the formation of a school of typical design and construction in the USSR and Ukraine.
Thus, the transition to the third stage in Ukrainian practice can be considered as important work in the field of construction technology and the search for economic housing, which occurred in parallel with the implementation of grandiose ambitious projects of the Stalin era [15 - 17].

Orientation by the Secretary General of the CPSU Central Committee, M. Khrushchev, to social programs [18], which arose from familiarity with the experience of a lifestyle in European countries, has led to a kind of revolution in architecture, urban planning and construction. The scale of reform in the Soviet Union and Ukraine is impressive, as well as the number of new design and research institutes and building organizations that have emerged. The presence of any decorative details in the shaping of architecture has since been crushed by criticism. The consequences of such an attitude by the authorities to the architectural heritage of the previous period of «Stalin centralization» contributed to the bitter disappointment and recognition of these years of decoration (Stalin's empire) as terrible for the architecture of the time (according to M. Barshch) (quoted by M.S. Ilchenko [6]). The main thesis for new directions of understanding of architectural formation and approach to creation of architectural form became economy, which envisaged extreme simplicity and possibility of industrial execution. In Khrushchev's time, there were appeared compositions made of ceramics on the first objects of public service, which were information-filled planes according to the functional purpose of the building. The announced new policy in architecture and construction was completely opposed to the previous era. The emphasized asceticism of the forms and the mass of typical housing and the extraordinary pace of construction aimed at promoting the ideas of the invincibility of the Soviet state, the greatness, the advantages of the socialist type of economy, which can all «catch up and overtake» the leading states of the world.

The harsh reality of the post-Stalinist time eventually morphed into a direction that purportedly continued the idea of restraint in shaping. But at the same time, the USSR 
formed a socialist camp from part of the European countries, the Council for Mutual Economic Assistance, the Warsaw Pact as a military union of states, and international cultural ties with the formation of relevant organizations were spreading. The leadership of the Soviet Union led the newly formed interstate alliances. The practice of cultural contacts between the USSR and the countries of the socialist camp automatically led to the borrowing of methods of creating an architectural and urban planning environment, typical construction, methods of forming the artistic image of buildings, and so on. Due to the expansion of the spatial and territorial range of Soviet influence onto the culture of other peoples and the leading role of the Soviet country in resolving purely professional issues regarding the reconstruction of historical centers of cities, threetier service system, organization of transport routes, etc., the USSR exerts pressure onto the leadership of friendly states through any manifestation of their independence in the directions of formation of architectural and urban planning environment [19].

Orientation to improve the architectural formation, that was proclaimed by the Resolution of the CPSU Central Committee and the Council of Ministers of the USSR in 1969 [20], contributed to the diversity of forms (Fig. $3, a, b)$, the spread of vertical division on the facade as elements of neoclassicism in representative buildings (Palace of Congresses) and the extraordinary spread of plane arts as an additional way of expressing the stateideological essence of the Soviet state (Fig. 3, $c, d)$. The mosaic was especially widespread (Fig. 3,e). A rather expensive means of synthesizing the arts in stingy rationalist forms of architecture reflected the plots of state grandeur, ideological content, and social propaganda. Mosaics over time have become an invariable attribute of Soviet architecture, giving ideological content to any structure, even urban and suburban bus stops, they constantly reminded of the joyful present and the expected bright future by their presence in the lives of the working masses.

\section{THE CONCLUSIONS}

Thus, the ideological component of a totalitarian Soviet state at all stages of its development was an indispensable feature of architecture. At the first post-October stage, it was a specific form of constructivism born in Soviet Russia that cannot be confused with European functionalism. As the main idea of the emergence of functionalism was contained, in addition to improving the living conditions of the society, in the fight against the negative effects of the spontaneously formed state of gigantic cities, due to the emergence of industrial territories in their suburbs, that surrounded the city with ring, prevented their connection with the natural environment and their further growth, facilitated the compacting of buildings and the formation of slums. That is, the program of functionalists was defined as the primary tasks of solving functional, social and sanitaryhygienic problems [21].

The stylistic trend was non-state, cosmopolitan. Constructivism, on the contrary, provided new, not existing architectural tools in order to demonstrate the ideology of workers and peasants in the architectural and urban environment.

In the second and third stages, the means of artistic expressiveness of the state-ideological direction were increased decoration of forms, the extraordinary spread of state and social symbolism and the means of art synthesis: in the Stalin period, it was the plastic arts, and later - the plane arts.

Finally, a comparison should be made between the Russian and Ukrainian legacies of the Soviet era. When Ukraine was part of the USSR, did she have any differences in the formation of the architectural and urban planning environment at that time, carefully following the orders of one-party power from Moscow? So! Studying the experience of design and construction of the Russian Federation and Ukraine and comparing them with each other allows us to draw the following conclusions.

1. The Russian artists were quicker to respond to the tasks, accomplish them with scope, were more inclined to convey the main 


\section{The period of Soviet modernism \\ $1954-1985$}
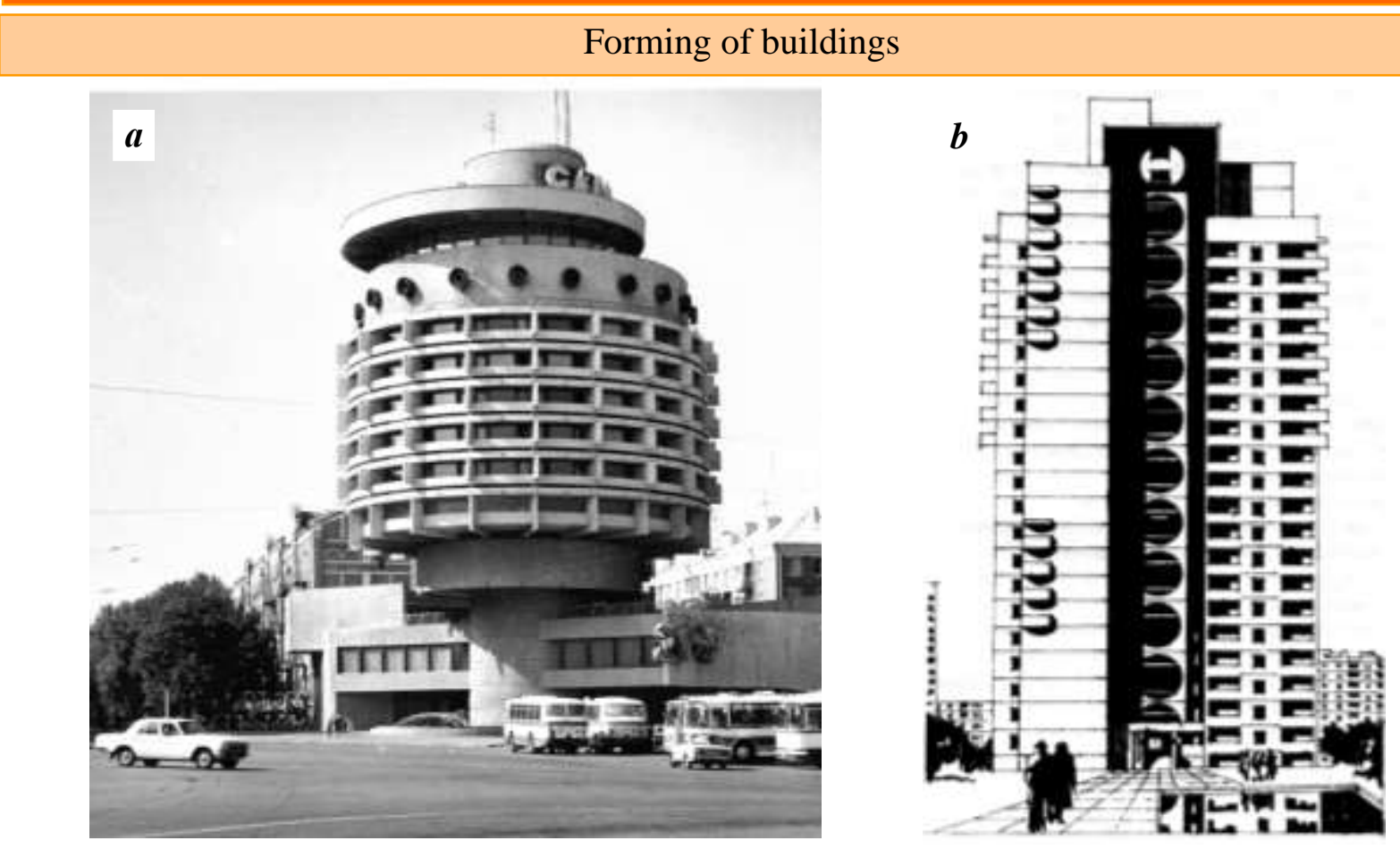

State and social symbolism
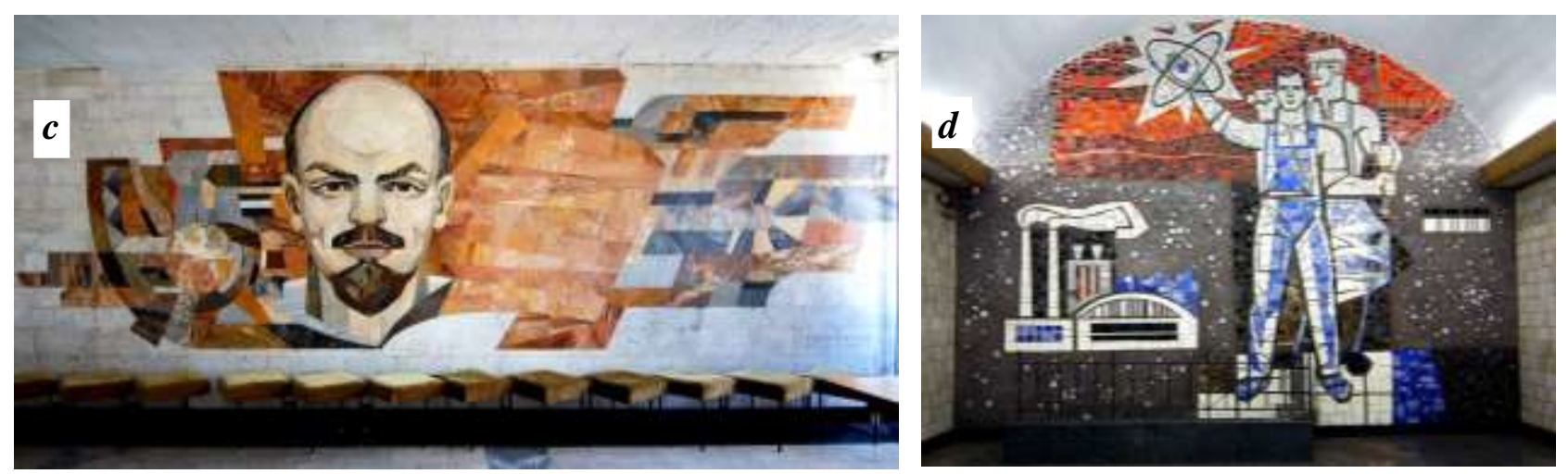

Synthesis of the arts - plane arts

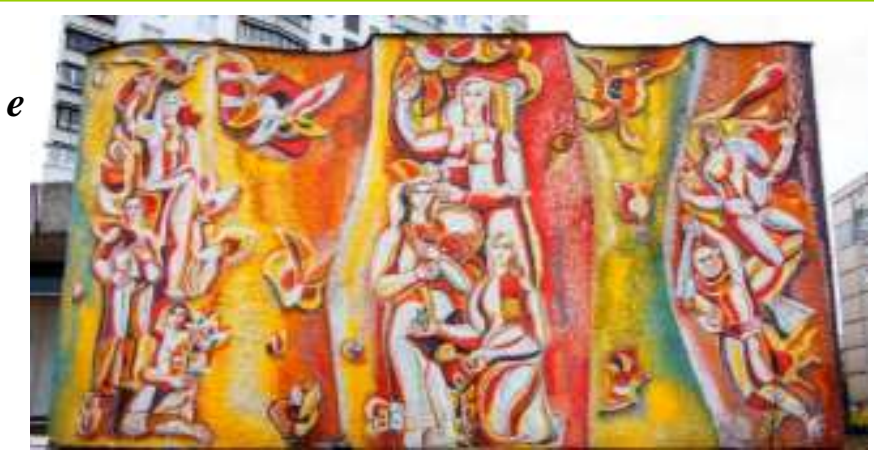

Fig.3. Examples of the Formation of Buildings and the Synthesis of the Arts as Means of State and Social Symbolism in Ukrainian Architecture of the Modernist Period: $a$-Salute Hotel, Kyiv; $b$ - facade of a 22-storey large panel apartment building of the APVS series on the str. Mostytska in Kyiv; $c$ - panel - photo by E Nikiforov; $d$ - panel in the interior of the Bolshevik subway (now called Shulyavka), Kyiv, Avt. I. Litovchenko, 1963, Peremoha avenue, 1967 - 1968, photo by E. Nikiforov; $e$ - mosaic in a residential complex in Kyiv. 
ideological thought and to implement it in the architectural and spatial organization. This is confirmed by competitive projects and completed structures (examples are Moscow skyscrapers [22-24]).

In Ukraine, the party-defined tasks were performed on a smaller scale and slower. Most likely, the reason was not only the periphery of the territory of Ukraine relative to Moscow, but also the mentality of Ukrainians, differences in their psychology, probably the conditions of territorial density of habitation, as psychologists point out $[25,26]$, the perception of orders from above as a pressure on a freedom-loving people.

2. At the first post-revolutionary stage of cultural development of the newly created state, a series of projects of Kharkiv as the first Ukrainian capital of workers was an example of the implementation of new trends in architecture and real construction in Soviet Ukraine. These are separate buildings, erected as variations on the theme of industrial architecture, the workers' village of KhTZ and the Metropolitan center of power on Sq. Dzerzhinsky (now the Freedom Square). Ukrainian architects sought perfection and reality in architectural solutions in accordance with the latest social needs, both in the functional part and in the artistic-figurative form.

All of these facilities, which were built in accordance with the revolutionary ideology of creating an environment for workers, have changed in appearance due to the length of construction and the emergence of new requirements for architecture. This is a testament to the further refusal of the use of functionalism in urban planning and constructivism in the architecture of buildings due to changes in policy and ideological tasks.

3. The plasticity of Stalinist architecture during the second period of socio-cultural development in Ukraine compared to Russia was relatively moderate. Large-scale compositions for the reconstruction of the capital (Kyiv), proposed in the competitive projects of Soviet architects (Russian), have not been implemented. Numerous sculpture groups on Khreshchatyk, which had to demonstrate the state majesty and happiness of the Soviet people, disappeared from the project immediately after the death of the Generalissimos, and in Kharkov and Kiev architects abandoned the tower completions that Stalin so loved.

4. In the third stage, the Russian mosaic panel prototypes had the emphasized ideological content, in Ukraine, they rather acquired the trait of folk art, became models of national culture, which received a negative assessment of state power, but it was welcomed by the Ukrainian people.

\section{REFERENCES}

1. Bachynska L.H. 2017. Vplyv politychnoho rezhymu SRSR u 1920-1940-vi roky na arkhitekturu ta mistobuduvannia UkrainyScience of the XXI century: Problems and prospects of researches. Proceedings of the International Scientific Conference. September 18, 2017, Warsaw, Poland. Vol.01, 15-20 (in Ukrainian).

2. Bachynska L.H. 2017. Evoliutsiia arkhitektury i mistobuduvannia Ukrainy $\mathrm{z}$ kintsia XX do pochatku XXI stolit: prychyny ta tendentsii. WORLD SCIENCE. № 10 (26), Vol. 01, October 2017. Dubai, UAE, 43-48 (in Ukrainian).

3. Bachynska L.H. 2017. Arkhitektura ta mistobuduvannia Ukrainy u perekhidni periody ekonomichno-politychnoho stanu XX stolittia. WORLD SCIENCE. № 11 (27), Vol. 01, November 2017. Warsaw, Poland, 40-46 (in Ukrainian).

4. Bachynska L.H. 2017. Ideolohichna transformatsiia obraza arkhitekturnoho obiekta yak vidobrazhennia dynamiky suspilnopolitychnykh umov. WORLD SCIENCE. № 12 (28), Vol. 1, November 2017. Warsaw, Poland 40-46 (in Ukrainian).

5. Ikonnikov A.V. 2001, 2002. Arkhitektura XX veka. Utopii i realnost. V 2 tomakh. Moskva, Progress-Tradicziya, Vol. 01, 656. Vol.02. 672 (in Russian).

6. Ilchenko M.S. 2013. Sovetskie arhitektoryi i institutyi vlasti v 1930 - 1950-h godah: strategii vzaimodeystviya. Vestnik Permskogo universiteta. Vol. 02 (22), 87-95 (in Russian).

7. Nikitina T.A., 2015. Dvortsyi Covetskogo perioda Materialy' IV Mezhunarodnoj konferenczii. Moskva, yanvar, 2015. Moskva: Inzhenerny'e nauki v Rossii. 82-91 https://moluch.ru/conf/tech/archive/124/6942 (in Russian).

8. Selivanova A.N., 2012. Dvizhenie ot mekhanizma $\mathrm{k}$ organizmu $\mathrm{v}$ arkhitekture postkonstruktivizma. Sokrashhenny`j variant doklada: 
Postkonstruktivizm 1930-kh godov: dvizhenie ot «mekhanizma» $\mathrm{k}$ «organizmu». Mezhdunarodnaya nauchnaya konferencziya pamyati akademika RAASN, doktora iskusstvovedeniya S.O. Khan-Magomedov (Moskva, 18-20 yanvarya 2012) https://archi.ru/lib/e publication. html?id=1850569915 (in Russian).

9. Lenskyi M.L., 1950. Velykyi natkhnennyk radianskoi arkhitektury. Visnyk Akademii arkhitektury URSR. № 01. 5-10 (In Ukrainian).

10.Pid slavnym praporom demokratyzmu, 1950. Visnyk Akademii arkhitektury URSR, No.01, 3-4 (in Ukrainian).

11.Mokrousova O., 2003 Tsementni meshkantsi Khreshchatyka, abo Zhyttya na fasadakh. Kulturna spadshchyna Kyieva: doslidzhennia ta zakhyst istorychnoho seredovyshcha, No.01, 113-123 (in Ukrainian).

12.Erofalov-Pilipchak B.L., 2010. Arkhitektura sovetskogo Kieva. Kyiv: Vidavnitstvo A S. 640 LII s .: Il. - RozdIl: Proekti 20 stolIttya, 154336 (in Russian).

13. Arkhitektura Radianskoi Ukrainy za 40 rokiv, 1957. Kyiv: Derzhavne vydavnytstvo literatury z budivnytstva ta arkhitektury URSR. 287 (In Ukrainian).

14. Postanovlenie CzK KPSS i Soveta Ministrov SSSR Ob ustranenii izlishestv v proektirovanii i stroitel`stve. 1955. Pravda, noyabr, 10 (in Russian).

15. Shteinberh Ya.A., 1949. Sporudzhennia zhylykh budynkiv Pivdenavtobudu v Dnipropetrovsku. Visnyk Akademii arkhitektury URSR. No.3, 11-18 (in Ukrainian).

16. Shteinberh Ya.A., 1950. Znyzyty vartist zhytlovoho budivnytstva. Visnyk Akademii arkhitektury URSR. No.3, 7-16 (in Ukrainian).

17. Shteinberh Ya.A., 1940. Vyhidne i ekonomichne zhytlo. Arkhitektura Radianskoi Ukrainy, No.4, 37-43 (in Ukrainian).

18.Danylenko V., 2011 Sproby «sotsializatsiyi» radyanskoyi ekonomiky $\mathrm{V}$ roky khrushchovskoyi «vidlyhy» (1955-1965 rr.). Ukraina XX stolittia: kultura, ideolohiia, polityka. № 16, 5-20 (in Ukrainian).

19.Goldzamt E.A., Shvidkovsky O.A., 1985. Gradostroitelnaya kultura yevropeyskikh sotsialisticheskikh stran Mosckva: Stroyizdat, 478 (in Russian).

20.Postanovlenie CzK KPSS i Soveta Ministrov SSSR O merakh po uluchsheniyu kachestva zhilishhno-grazhdanskogo stroitel`stva. 1969. 28 travnia 1969, No.392. http://www. economics.kiev.ua/download/ZakonySSSR/d ata03/tex15165.htm (in Russian).
21.Bunin A.V., Savarenskaya T.F., 1979 Istoriya gradostroitel'nogo iskusstva: V 2-kh t. Tom 2. Gradostroitelstvo XX veka v stranakh kapitalisticheskogo mira. Moskva: Stroyizdat (in Russian).

22.Barkhin A.D., 2016. Ar-deko i istorizm v arkhitekture moskovskikh vysotnykh zdaniy. Voprosy vseobshchey istorii arkhitektury (electronic journal). Vol.06. http://www.niitiag.ru/ pub/pub cat/voprosy vseobschey istorii arkhit ektury_6 (in Russian).

23.Legendarny`e stalinskie vy`sotki, 2017. http://tursputnik.com/2017/04/legendarnyestalinskie-vysotki.html (in Russian).

24.Sovetskij monumental'nyj klassiczizm v arkhitekture Moskvy`. 1930-1950-e gody, 2010. meta3/ 29 noyabrya 2010 goda, 10:45 vechera Moskva, arhitektura, SSSR.19220 http:// mynnm.ru/blogs/meta3/sovetskiy monumental nyy_klassicizm_v_arhitekture_moskvy_1930_1950-e gody (in Russian).

25.Gubko O., 2013. Psykholohiia ukrainskoho narodu: naukove doslidzhennia u 2-kh $\mathrm{kn}$. Knyha 2: Psykholohichni osoblyvosti nashykh kraian u mizhchassi Trypillia - suchasna Ukraina. Vydavnytstvo «Dilo» 400 (in Ukrainian).

26.Kondratenko V., 2018. Physiological model of one materialized human thought. Transfer of Innovative Technologies, Vol.1, No.2, 82-88.

\section{Синтез искусств в советской архитектуре: этапы развития, главные направления, причины их появления}

\section{Людмила Бачинская}

Аннотация. История Советского Союза, его социально-экономической, социально-политической и социально-культурной жизни является уникальной в сравнении с другими странами. СССР был создан по модели общественного развития, сформулированной еще европейскими и российскими социалистами-утопистами, и обоснован классиками марксизма-ленинизма. Поэтому система правления, экономические условия и культурная деятельность общества, построенного на гегемонии пролетариата, была продолжительным социальным экспериментом, который обусловил жизнедеятельность советского народа и повлиял на другие страны.

Эксперимент страны с тотальной государственной собственностью предполагал, что партийная верхушка брала на себя ответственность определять все сферы политической жиз- 
ни - и внутриполитической, и межгосударственные отношения - и неминуемо формировала единые программы культурной деятельности и общественного развития, руководила ими, осуществляла финансирование и жесткий контроль за их выполнением. Советский народ, так называемые «трудящиеся массы» были вынуждены жить и действовать по единым правилам В зависимости от планирования партийным руководством политико-экономической и общественной жизни в течение всего существования СССР страна пережила несколько этапов, которые отличались по основным направлениям формирования архитектурноградострои-тельной среды. Среда должна была отвечать заданиям государственноидеологического характера. Ознакомление с этим уникальным опытом и поиск причин его создания является важным для понимания тенденций общественного развития в XX столетии.

Ключевые слова: Советский Союз, Украина, социально-культурная деятельность, влияние политико-экономических условий, архитектура и градостроительство. 